\title{
Cerebral Salt-Wasting Syndrome in a Patient with Subacute Sclerosing Panencephalitis: The Use of Fludrocortisone in Treatment
}

\author{
Subakut Sklerozan Panensefalitli Bir Hastada Serebral Tuz Kaybı Sendromu: Tedavide \\ Fludrokortizon Kullanımı
}

\author{
(D) Orkun Tolunay, (D) Tamer Çelik, (D) Aysu İlhan Yalaki, (D) Duygu Artar, (D) Ümit Çelik \\ Adana City Training and Research Hospital, Clinic of Pediatrics, Adana, Turkey
}

\section{Abstract}

Cerebral salt wasting syndrome (CSWS) is characterized by natriuresis and associated with hypovolemia, and hyponatremia. The underlying pathogenesis is not clearly known. It is often confused with syndrome of inappropriate anti-diuretic hormone release. Volume repletion and sodium replenishment and correction of the underlying cause are the most important components of treatment. As the awareness of CSWS, which is frequently described in neurosurgical patient, increases, the number of patients diagnosed increases and new factors are gradually defined in the etiology. In this study, we present a 16-year-old male patient, who was followed with the diagnosis of subacute sclerosing panencephalitis and developed CSWS and did not recover from hyponatremia despite sodium replenishment, and was successfully treated with fludrocortisone.

Keywords: Cerebral salt-wasting syndrome, hyponatremia, subacute sclerosing panencephalitis, syndrome of inappropriate antidiuretic hormone release

\section{Öz}

Serebral tuz kaybı sendromu, natriürez ve diürezin neden olduğu, hipovolemik hiponatremi tablosu olup, patogenezi net olarak bilinmemektedir. Sıklıkla uygunsuz antidiüretik hormon salınımı sendromu ile karıştırılmaktadır. Serebral tuz kaybı sendromu tedavisinde, volüm ve sodyum kaybının yerine konulması ve altta yatan nedenin düzeltilmesi tedavinin en önemli öğeleridir. Sıklıkla beyin cerrahisi operasyonlarından sonra tariflenen serebral tuz kaybı sendromunun bilinirliği arttıkça tanı konulan hasta sayısı artmakta ve etiyolojide her geçen gün yeni etkenler tanımlanmaktadır. Burada subacute sclerosing panencephalitis tanısıyla izlenmekte olan, izleminde serebral tuz kaybı sendromu gelişen, sodyum defisit tedavisine rağmen hiponatremisi düzelmeyen ve fludrokortizon ile başarılı şekilde tedavi edilmiş 16 yaşında bir olgu sunulmuştur.

Anahtar Kelimeler: Serebral tuz kaybı sendromu, hiponatremi, subakut sklerozan panensefalit, uygunsuz antidiüretik hormon salınımı sendromu

\section{Introduction}

Hyponatremia is one of the most common electrolyte problems encountered in hospitalized children. ${ }^{1-3}$ Most cases are asymptomatic and are noticed by routine blood tests. To treat hyponatremia in the most appropriate way, it is necessary to determine the underlying cause. The most common cause of hyponatremia in hospitalized children is hypotonic fluid therapy, syndrome of inappropriate antidiuretic hormone release (SIADH) and cerebral salt wasting syndrome (CSWS). ${ }^{3}$ While it is thought that SIADH was seen more frequently than CSWS in the past years, CSWS cases have been increasing every year, and it is considered to be more frequent than expected. ${ }^{2,4,5}$ Some authors claim that CSWS is seen more often than SIADH, particularly in cerebral diseases. ${ }^{5}$ A patient with CSWS may be misdiagnosed, and unnecessary fluid restriction may lead to worsening of hypovolemia and dehydration. ${ }^{1-4}$ Herein, we present a patient who was followed with the diagnosis of subacute sclerosing panencephalitis (SSPE), followed by CSWS, did not recover from hyponatremia despite sodium replenishment and successfully treated with fludrocortisone eventually.

Address for Correspondence/Yazışma Adresi: Orkun Tolunay MD, Adana City Training and Research Hospital, Clinic of Pediatrics, Adana, Turkey

E-mail: orkuntolunay@yahoo.co.uk ORCID ID: orcid.org/0000-0003-0714-6734

Received/Geliș Tarihi: 27.03.2018 Accepted/Kabul Tarihi: 15.05.2018

${ }^{\circ}$ Copyright 2019 by Society of Pediatric Emergency and Intensive Care Medicine

Journal of Pediatric Emergency and Pediatric Intensive Care published by Galenos Yayınevi. 


\section{Case Report}

A 16-year-old male patient with the diagnosis of SSPE was admitted to the pediatric intensive care unit due to respiratory failure. After endotracheal intubation, the patient started to be monitored on mechanical ventilator. Extubation was attempted after pneumonia therapy causing respiratory insufficiency. Tracheotomy and gastrostomy were planned upon extubation failure. During this period, hyponatremia $(130 \mathrm{mEq} / \mathrm{L})$ was detected (Figure 1). The patient was fed via the enteral and intravenous routes, and his sodium intake was appropriate. There was no medication expected to cause hyponatremia in the treatment. No diarrhea, vomiting, hypothyroidism, adrenal insufficiency, pulmonary disease, congestive heart failure, and acute or chronic kidney failure was detected on physical examination and laboratory tests. His medical history and the laboratory tests results were also unremarkable despite hyponatremia. The patient was initiated sodium replacement therapy and did not require fluid loading due to absence of dehydration. His serum sodium value was $126 \mathrm{mEq} / \mathrm{L}$ and the urine sodium value was $196.9 \mathrm{mmol} / \mathrm{L}$. Hyponatremia, polyuria $(3.6 \mathrm{~mL} / \mathrm{kg} / \mathrm{h})$, and natriuresis led us to consider CSWS. As no improvement was seen with the sodium deficit treatment, replacement fludrocortisone $(2 \times 0.1 \mathrm{mg})$ was initiated on the $8^{\text {th }}$ day of hyponatremia and on the $7^{\text {th }}$ day of sodium deficit treatment replacement. After treatment with fludrocortisone, the need for the treatment of sodium deficiency decreased and sodium deficit treatment replacement was discontinued on the $4^{\text {th }}$ of fludrocortisone treatment. Sodium levels returned to normal and fludrocortisone treatment was down-titrated and discontinued on day 8 (Figure 1).Written informed consent was not obtained due to the retrospective nature of this study.

\section{Discussion}

Cerebral salt-wasting syndrome was first described in 1950. Peters et al. reported three patients with central nervous system diseases and hyponatremia, renal sodium loss, and dehydration without hypothalamic, pituitary or adrenal

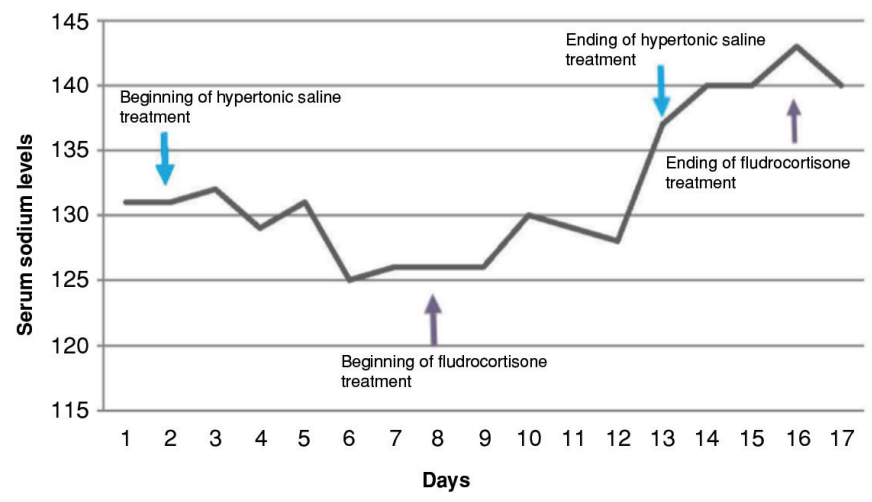

Figure 1. Serum sodium levels and fludrocortisone treatment gland problems. ${ }^{1,5,6,7}$ Following the definition of the SIADH by Schwartz ${ }^{6}$ in 1957, CSWS was almost ignored, until the 1980s. ${ }^{17,8}$ Although CSWS has been considered a variant of SIADH in the past years, it has been recognized as a different entity with the introduction of pathophysiology in recent years. ${ }^{1,2,5,9}$ Subarachnoid hemorrhage, cerebral operations, infections, head trauma, brain tumors, and stroke are among the etiological factors of CSWS. 1,2,10,11 New causes have been also increasingly suggested as the main etiological factor. ${ }^{2,11}$ In the clinical presentation, this syndrome manifests with excessive urinary output, extreme sodium excretion in the urine, and extracellular fluid loss-dehydration and hyponatremia. ${ }^{1,2,4}$

CSWS has been attempted to be explained by a decrease in sympathetic tone to the kidneys and an increase in the natriuretic peptides. ${ }^{11}$ Sympathetic stimulation increases the reabsorption of sodium, uric acid and water in the proximal tubule, and secretion of renin. In reduced sympathetic stimulation theory, these mechanisms are ineffective. Therefore, volume loss and loss of sodium occur. ${ }^{1,2}$

Natriuretic peptides, such as atrial natriuretic peptide (ANP) and brain natriuretic peptide (BNP), are remarkable in the pathophysiology of CSWS. Natriuretic peptide and BNP induce diuresis and natriuresis by increasing glomerular filtration rate. ${ }^{1,2}$

Increased intracranial pressure is considered to be caused by CSWS, leading to an increase in natriuretic peptides in the cerebrospinal fluid. ${ }^{12,13}$ Therefore, it is essential to reduce intracranial pressure (ventriculo-peritoneal shunt placement or external drainage placement), particularly in patients with hydrocephalus. ${ }^{12,13}$

In the literature, there is only one reported case of a patient who was followed with the diagnosis of SSPE and developed CSWS. The patient was successfully treated with sodium and fluid replacement therapy. ${ }^{14}$

Several criteria have been defined for the diagnosis of CSWS, and one of the most frequently used ones is defined by Jimenez $(2,14), 2,15$ Jimenez's criteria include hyponatremia (plasma $\mathrm{Na}<130 \mathrm{mEq} / \mathrm{L}$ ), increased urine sodium level $(>120$ $\mathrm{mEq} / \mathrm{L})$, increased urinary osmolarity $\left(>300 \mathrm{mOsm} / \mathrm{kgH}_{2} \mathrm{O}\right)$, increased urine volume $(>3 \mathrm{~mL} / \mathrm{kg} / \mathrm{h})$, and negative liquid balance in the last 24 hours. ${ }^{15}$ Inappropriate-hypotonic fluid therapy, diuretic use, SIADH, congestive heart failure, renal-liver diseases, hypothyroidism, and adrenal insufficiency should be considered in the differential diagnosis of hyponatremia in hospitalized children.

Measurement of serum ADH and ANP-BNP levels in the differential diagnosis of hyponatremia is impractical and can be confusing. Although ANP and BNP levels are thought to be high in CSWS, cases with normal ANP-BNP levels have also been reported. ${ }^{11}$ Although low serum uric acid levels have 
been reported in patients with SIADH, serum uric acid levels also decrease in CSWS, whereas the fractional excretion of uric acid is also increased. ${ }^{1,11}$

As we know that the most common causes of hyponatremia in hospitalized children are inappropriate fluid therapy/hypotonic fluid therapy, we checked our patient that there was no drug use that could cause hyponatremia. The patient was fed via the enteral and intravenous routes, his sodium intake was appropriate, and there was no medication expected to cause hyponatremia in the treatment. No diarrhea, vomiting, hypothyroidism, adrenal insufficiency, pulmonary disease, congestive heart failure, and acute or chronic kidney failure was detected on his physical examination and laboratory tests. Furthermore, there was no dehydration, as fluid balance was maintained on time. Since hyponatremia persisted despite sodium replacement, fludrocortisone was added to the treatment. It is known that natriuretic peptides suppress mineralocorticoid release in patients with CSWS. ${ }^{11}$ Thus, the use of an agent with mineralocorticoid activity, such as fludrocortisone, was considered and it was found that fludrocortisone elevated the serum sodium level to the normal levels. ${ }^{2,16}$ The use of $0.1 \mathrm{mg}$ fludrocortisone (p.o.) once or twice a day is successful in patients who fail to respond to sodium and fluid replacement. 2,3,11,16 The treatment of CSWS should be based on the underlying causes.

\section{Conclusions}

In conclusion, the prevalence of CSWS has been increased in hospitalized children, particularly in the etiology of hyponatremia, which is common in intensive care units. Late or false diagnosis increases morbidity and mortality. As patients' fluid status is closely monitored in hospital, CSWS diagnosis should not be avoided in patients without dehydration. Serum sodium, urine sodium and polyuria should be considered first in diagnosis. In addition, supporting laboratory tests such as uric acid and BNP should not be ordered routinely. Clinical and laboratory characteristics of CSWS in hospitals with inpatient service, particularly in pediatric intensive care units, should be known in detail. The use of fludrocortisone in patients who do not respond to sodium replacement is beneficial.

\section{Ethics}

Informed Consent: Written informed consent was not obtained due to the retrospective nature of this study.

Peer Review: Externally and internally peer-reviewed.

\section{Authorship Contributions}

Concept: O.T., Ü.Ç., Design: O.T., T.Ç., Data Collection or Processing: A.I.Y., D.A., O.T., Analysis or Interpretation: O.T., Ü.Ç., T.Ç., Literature Search: O.T., Ü.Ç., A.I.Y., D.A., T.Ç., Writing: O.T.
Conflict of Interest: No conflict of interest was declared by the authors.

Financial Disclosure: The authors declared that this study has received no financial support.

\section{References}

1. Oh JY, Shin Jl. Syndrome of inappropriate antidiuretic hormone secretion and cerebral/renal salt wasting syndrome: similarities and differences. Front Pediatr. 2015;22;146.

2. Celik T, Tolunay O, Tolunay I, Celik U. Cerebral Salt Wasting in Status Epilepticus: Two Cases and Review of the Literature. Pediatr Neurol. 2014;50:397-9

3. Thompson C, Berl T, Tejedor A, Johannsson G. Differential diagnosis of hyponatraemia. Best Pract Res Clin Endocrinol Metab. 2012;26:7-15.

4. Rivkees SA. Differentiating appropriate antidiuretic hormone secretion, inappropriate antidiuretic hormone secretion and cerebral salt wasting: the common, uncommon, and misnamed. Curr Opin Pediatr. 2008;20:448-52.

5. Diringer M, Ladenson W, Borel C, Hart GK, Kirsch JR, et al. Sodium and water regulation in a patient with cerebral salt wasting. Arch Neurol. 1989;46:928-30.

6. Schwartz WB, Bennett W, Curelop S, Bartter FC. A syndrome of renal sodium loss and hyponatremia probably resulting from inappropriate secretion of antidiuretic hormone. Am J Med. 1957;23:529-42

7. PETERS JP, WELT LG, SIMS EA, ORLOFF J, NEEDHAM J. A saltwasting syndrome associated with cerebral disease. Trans Assoc Am Physicians. 1950;63:57-64

8. Nelson PB, Seif SM, Maroon JC, Robinson AG. Hyponatremia in intracranial disease: perhaps not the syndrome of inappropriate secretion of antidiuretic hormone (SIADH). J Neurosurg. 1981;55:938-41.

9. Palmer, B.F. Hyponatremia in patients with central nervous system disease: SIADH versus CSW. Trends Endocrinol Metab. 2003;14:182-7.

10. Berkenbosch JW, Lentz CW, Jimenez DF, Tobias JD. Cerebral salt wasting syndrome following brain injury in three pediatric patients: suggestions for rapid diagnosis and therapy. Pediatr Neurosurg. 2002;36:75-9.

11. Tolunay $\mathrm{O}$, Çelik T, Çelik Ü, Kömür M, Yağcı-Küpeli B. Cerebral salt wasting in pediatric critical care; not just a neurosurgical disorder anymore. Neuro Endocrinol Lett. 2015;36:578-82.

12. Doczi TP, Joo F, Balas I. Atrial natriuretic peptide (ANP) attenuates brain oedema accompanying experimental subarachnoid haemorrhage. Acta Neurochir (Wien). 1995;132:87-91.

13. Berendes $E$, Walter $M$, Cullen $P$, Pirien $T$, Van Aken $H$, et al Secretion of brain natriuretic peptide in patients with aneurysmal subarachnoid haemorrhage. Lancet. 1997;349:245-9.

14. Çalık $M$, İşcan $A$, Abuhandan $M$, Geter S, Ataş A, et al. Cerebral salt wasting syndrome in a child with SSPE. J Pediatr Neurol. 2012;10:221-24

15. Jimenez R, Casado-Flores J, Nieto M, García-Teresa MA. Cerebral salt wasting syndrome in children with acute central nervous system injury. Pediatr Neurol. 2006;35:261-3.

16. Sakarcan A, Bocchini J. The role of fludrocortisone in a child with cerebral salt wasting. Nephrol. 1998;12:769-71. 